\title{
Environmental correlates of species richness of Sesiidae (Lepidoptera) in Europe
}

\author{
MAREK BĄKOWSKI ${ }^{1}$, WERNER ULRICH ${ }^{2}$ and ZDENĚK LAŠTU゚VKA ${ }^{3}$ \\ ${ }^{1}$ Adam Mickiewicz University, Department of Systematic Zoology, Umultowska 89, 61-614 Poznań, Poland; \\ e-mail: bakowski@amu.edu.pl \\ ${ }^{2}$ Nicolaus Copernicus University in Toruń, Department of Animal Ecology, Gagarina 9, 87-100 Toruń, Poland; \\ e-mail: ulrichw@umk.pl \\ ${ }^{3}$ Mendel University of Agriculture and Forestry in Brno, Department of Zoology, Fisheries, Hydrobiology and Apidology, \\ Zemědělská 1, 61300 Brno, Czech Republic; e-mail: last@mendelu.cz
}

Key words. Lepidoptera, Sesiidae, species-area relationship, rhizophagous, xylophagous, macroecology, spatial autoregression, latitudinal gradient

\begin{abstract}
Recent compilations of species richness for 54 European countries and large islands and linear spatial autocorrelation modelling were used to infer the influence of area and environmental variables on the number of species of clearwing moths (Sesiidae) in Europe. Area corrected species richness of rhizophagous Sesiidae peaked at about $40^{\circ} \mathrm{N}$ and decreased towards higher and lower latitudes. Most species rich was Greece (45 species), Bulgaria (37), Italy (35) and Romania (35). The area corrected species richness of xylophagous Sesiidae peaked at about $45^{\circ} \mathrm{N}$ with France (24) and Italy (22) being most species rich. Species richness was significantly positively correlated with area and the average yearly difference in temperature, and significantly negatively correlated with latitude. Island and mainland SAR slopes did not differ significantly, however island species richness per unit area appeared to be about 2 to 2.5 times lower than mainland species richness.
\end{abstract}

\section{INTRODUCTION}

Area and latitude can be used to predict large-scale variation in species richness of animals and plants (cf. Rosenzweig, 1995; Brown \& Lomolino, 2005; Field et al., 2008). Species richness usually increases with area (Rosenzweig, 1995; Dengler, 2009), a pattern that is most often described by a power function (Rosenzweig, 1995; Drakare et al., 2006) of the form $\mathrm{S}=\mathrm{S}_{0} \mathrm{~A}^{\mathrm{z}}$, where $\mathrm{S}$ denotes the species richness of a given area $\mathrm{A}$ (the $\gamma$-diversity at maximum A), $S_{0}$ denotes the species richness per unit area ( $\alpha$-diversity) and the slope $z$ describes spatial species turnover ( $\beta$-diversity). Most of the slopes for mainland taxa vary between 0.1 and 0.3 , with those for islands generally greater (Drakare et al., 2006). This species-area relationship (SAR) is attributed to area per se, but as habitat heterogeneity increases with area it is this which possibly allows more species to coexist (Rosenzweig, 1995).

A second major predictor of large scale species richness is latitude (Hawkins et al., 2003). With few exceptions (sawflies, ichneumonids and aphids) species richness of a given taxon peaks around the equator (Rohde, 1992; Hillebrand, 2004). However, latitude per se does not control species richness (Hawkins \& Diniz-Filho, 2004). Latitude is an aggregate variable that integrates mainly variables connected with latitudinal gradients in climate (Currie et al., 2004; Hawkins et al., 2007), productivity and evapotranspiration (Field et al., 2008). For instance in European bats and springtails the gradient in winter length and annual maximum temperature is important (Ulrich et al., 2007; Ulrich \& Fiera, 2009). Keil \& Konvička (2005) and
Keil et al. (2008a, b) report that evapotranspiration is a major predictor of European hoverfly and dragonfly species richness. In addition, postglacial colonization trajectories from glacial refuges combined with limitations on dispersal influence present day differences in species richness of bats (Horáček et al., 2000) and trees in Europe (Svenning \& Skov, 2007).

Recent species distribution models focus on vertebrates, vascular plants and a few invertebrate taxa like butterflies (Dennis et al., 1998; Ulrich \& Buszko, 2003a) dung beetles (Lumaret \& Lobo, 1996), longhorn beetles (Baselga, 2008), hover- and dragonflies (Keil et al., 2008a, b) and springtails (Ulrich \& Fiera, 2009). The present study investigates whether species richness of clearwing moths (Sesiidae) in Europe can be explained in terms of geography.

Clearwing moths are mostly diurnal. Their larvae are endophagous mainly in the roots and to a lesser extent in stems of herbaceous plants (rhizophagous) and twigs, stem and/or roots of woody plants (xylophagous). Species that feed on herbaceous plants are usually less mobile and probably do not leave their habitat; in contrast many xylophagous species can be found far away from their hostplants. Most sesiid larvae are oligophagous, but some are monophagous (about 20\%) and polyphagy is rare, e.g. in Synanthedon spuleri.

Individual species differ greatly in their ecological requirements, but only some species are more specialized in their climatic or habitat requirements than their hostplants and have a less extensive range than their hosts (Špatenka et al., 1999). Xylophagous species are largely independent of habitat humidity while the rhizophages are 


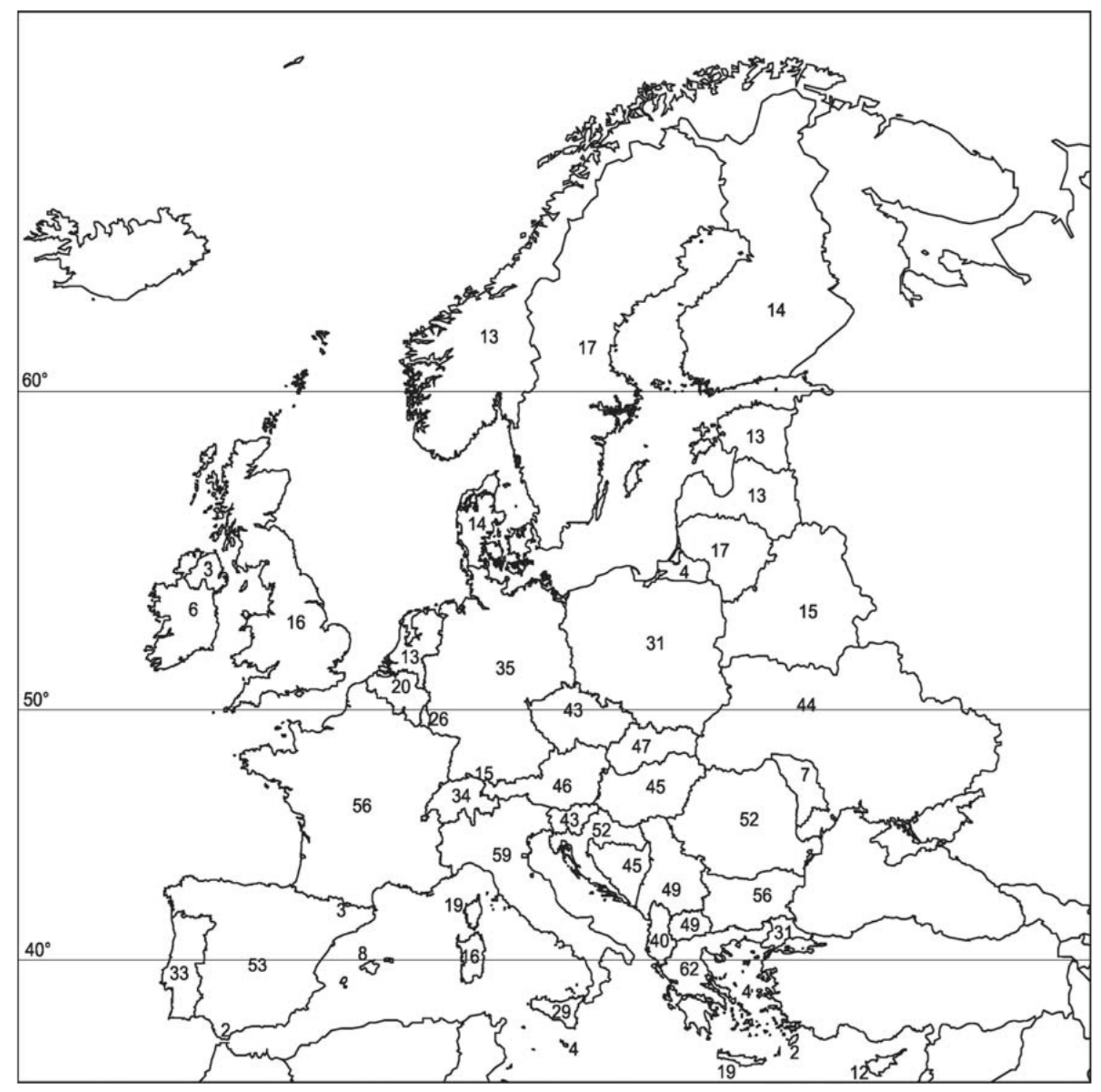

Fig. 1. Spatial distribution of sesiid species richness in Europe.

usually xerophilous. However, the presence of appropriate host-plants might override these constraints, as in Chamaesphecia aerifrons and C. alysoniformis, which can live in dry and in moist habitats if appropriate hostplants are present.

In the present paper four major predictions about the geographical factors that should influence large scale patterns of species richness are tested.

1. Species richness is significantly positively correlated with area and the average yearly difference in temperature and significantly negatively correlated with latitude (Hawkins et al., 2003; Hawkins \& Diniz-Filho, 2004; Field et al., 2008). Species richness should peak in Mediterranean countries and decrease continuously towards the north (Willig et al., 2003).

2. According to the habitat preferences of rhizophagous species (Laštůvka, 1990; Laštůvka \& Laštůvka, 2001; Špatenka et al., 1999) the number of herbivorous species should decrease with increasing latitude. In turn, the number of xylophagous species should increase towards higher latitude.

3. According to the theory of island biogeography (MacArthur \& Wilson, 1967) islands and mainlands should differ in species numbers even after correcting for area, geographical heterogeneity, temperature and latitude. Of particular importance for Sesiidae is the number and diversity of potential host plants. Plant species richness might therefore act as a surrogate variable of heterogeneity.

4. A recent analysis points to the southern part of the Balkans and Turkey as the main glacial refugia of Sesiidae in the Western Palaearctic (Špatenka et al., 1999). Therefore, whether post-glaciation patterns of colonization shifted richness peaks towards other European regions is also investigated.

\section{MATERIAL AND METHODS}

The results of recent taxonomic revisions and faunal surveys are used to update the faunal composition of 66 countries (main- 
TABLE 1. The species richness of rhizophagous and xylophagous Sesiidae of European countries and large islands included in the present study (data from Bartsch, 2004; Bartsch \& Pühringer, 2005; Bartsch et al., 2005; Bartsch \& Kallies, 2008; Kokot, 2005; Laštůvka, 2004; Laštůvka \& Laštůvka, 2008; Predovnik, 2005).

\begin{tabular}{|c|c|c|c|c|c|}
\hline Country & Area $\left(\mathrm{km}^{-2}\right)$ & $\Delta \mathrm{T}$ & $\begin{array}{l}\text { Number of xylo- } \\
\text { phaous species }\end{array}$ & $\begin{array}{l}\text { Number of rhizo- } \\
\text { phagous species }\end{array}$ & $\begin{array}{c}\text { Total number } \\
\text { of species }\end{array}$ \\
\hline Albania & 28748 & 17 & 14 & 26 & 40 \\
\hline Andorra & 468 & 15 & 1 & 2 & 3 \\
\hline Austria & 83871 & 20 & 21 & 25 & 46 \\
\hline Balearic Islands & 5014 & 15 & 4 & 4 & 8 \\
\hline Belarus & 207650 & 23 & 11 & 4 & 15 \\
\hline Belgium & 30528 & 15 & 14 & 6 & 20 \\
\hline Bosnia and Herzegovina & 51197 & 20 & 18 & 27 & 45 \\
\hline Bulgaria & 110971 & 21 & 19 & 37 & 56 \\
\hline Canary Islands & 7270 & 5 & 0 & 2 & 2 \\
\hline Channel Islands & 300 & 10 & 1 & 0 & 1 \\
\hline Corsica & 8680 & 13 & 4 & 12 & 16 \\
\hline Crete & 8259 & 13 & 5 & 14 & 19 \\
\hline Croatia & 56594 & 21 & 20 & 32 & 52 \\
\hline Cyprus & 9250 & 19 & 1 & 11 & 12 \\
\hline Czech Republic & 78866 & 19 & 21 & 22 & 43 \\
\hline Denmark & 43093 & 16 & 11 & 3 & 14 \\
\hline Dodecanese Islands & 2663 & 14 & 0 & 2 & 2 \\
\hline Estonia & 45227 & 21 & 10 & 3 & 13 \\
\hline European part of Turkey & 23764 & 18 & 9 & 22 & 31 \\
\hline Finland & 338145 & 23 & 12 & 2 & 14 \\
\hline France & 543965 & 15 & 26 & 30 & 56 \\
\hline Germany & 357021 & 19 & 20 & 15 & 35 \\
\hline Gibraltar & 6.5 & 10 & 0 & 2 & 2 \\
\hline Greece & 131992 & 17 & 17 & 45 & 62 \\
\hline Hungary & 93054 & 22 & 18 & 27 & 45 \\
\hline Ireland & 70273 & 10 & 5 & 1 & 6 \\
\hline Italy & 301401 & 16 & 24 & 35 & 59 \\
\hline Kaliningrad Region & 15000 & 19 & 3 & 1 & 4 \\
\hline Latvia & 64626 & 20 & 10 & 3 & 13 \\
\hline Liechtenstein & 160 & 14 & 12 & 3 & 15 \\
\hline Lithuania & 65318 & 22 & 14 & 3 & 17 \\
\hline Luxembourg & 2588 & 16 & 18 & 8 & 26 \\
\hline Macedonia & 25339 & 23 & 18 & 31 & 49 \\
\hline Madeira & 789 & 5 & 1 & 0 & 1 \\
\hline Malta & 316 & 14 & 1 & 3 & 4 \\
\hline Moldova & 33709 & 23 & 5 & 2 & 7 \\
\hline Netherlands & 41536 & 14 & 9 & 4 & 13 \\
\hline North Aegean Islands & 3886 & 18 & 2 & 2 & 4 \\
\hline Northern Ireland & 14144 & 9 & 3 & 0 & 3 \\
\hline Norway & 323963 & 21 & 11 & 2 & 13 \\
\hline Poland & 312766 & 20 & 20 & 11 & 31 \\
\hline Portugal & 91854 & 12 & 13 & 20 & 33 \\
\hline Romania & 237453 & 23 & 17 & 35 & 52 \\
\hline San Marino & 61 & 14 & 0 & 1 & 1 \\
\hline Sardinia & 23813 & 14 & 7 & 12 & 19 \\
\hline Serbia and Montenegro & 102199 & 20 & 17 & 32 & 49 \\
\hline Sicily & 25426 & 13 & 9 & 20 & 29 \\
\hline Slovakia & 49049 & 22 & 21 & 26 & 47 \\
\hline Slovenia & 20273 & 20 & 21 & 22 & 43 \\
\hline Spain & 505988 & 18 & 22 & 31 & 53 \\
\hline Sweden & 449964 & 20 & 14 & 3 & 17 \\
\hline Switzerland & 41285 & 19 & 21 & 13 & 34 \\
\hline Ukraine & 603886 & 24 & 17 & 27 & 44 \\
\hline United Kingdom & 244064 & 13 & 12 & 4 & 16 \\
\hline
\end{tabular}




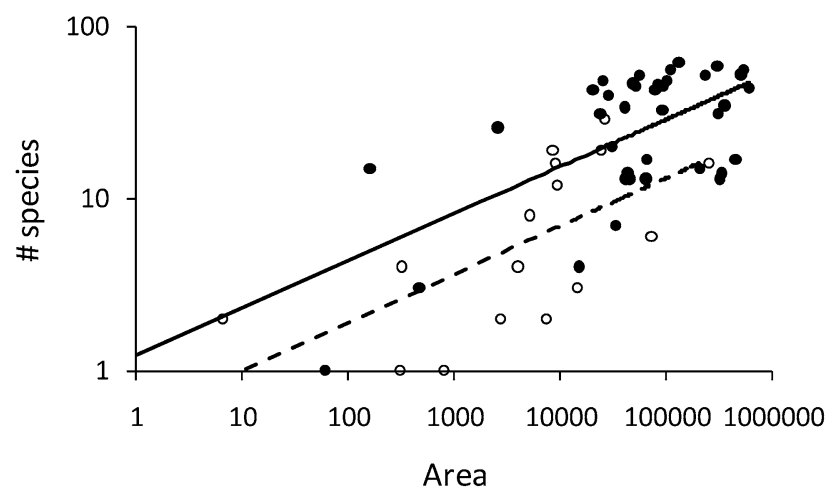

Fig. 2. Species area relationships of Sesiidae for islands (open circles) and mainland (dots) in Europe. Island ordinary least squares regression (broken line): $\mathrm{S}=(0.52 \pm 0.81) \mathrm{A}^{(0.28 \pm 0.09)} ; \mathrm{R}^{2}$ $=0.40 ; \mathrm{p}($ slope $=0)<0.01$. Mainland ordinary least squares regression (continuous line): $\mathrm{S}=(1.23 \pm 0.64) \mathrm{A}^{(0.27 \pm 0.06)} ; \mathrm{R}^{2}=$ $0.38 ; \mathrm{p}($ slope $=0)<0.001$.

land and large islands regardless of national affiliation) mentioned in Fauna Europaea (Laštůvka, 2004). Additionally, recent (recorded after 2004) descriptions and findings of single species for certain countries and islands were also used (Bartsch, 2004, Bartsch et al., 2005, Bartsch \& Pühringer, 2005; Bartsch \& Kallies, 2008; Kokot, 2005; Laštůvka \& Laštůvka, 2008; Predovnik, 2005). For 54 countries and large islands reliable recent faunistic surveys are available (Fig. 1; Table 1). The Azores, Cyclade Islands, Monaco and some other small islands were not considered due to undersampling. For the same reason Russia was omitted. Double entries in the case of subspecies were also corrected. In total the present paper is based on 133 European species and subspecies of Sesiidae (Table 1) of which 94 are rhizophagous and 39 xylophagous.

In order to test the predictions of the four hypotheses mentioned above the influence of four geographical and climate variables on sesiid species richness were evaluated. For each European country and large island included in the study (Table 1) the area in $\mathrm{km}^{2}$ and the latitude and longitude of its capital or (in the case of islands) its main city (data from World Atlas, http://www.worldatlas.com/atlas/world.htm) were determined. As an estimate of topographical heterogeneity $(\mathrm{H})$ the quotient of highest altitude of a country or island area was used (Ricklefs et al., 2004). The average annual temperatures $T_{\text {mean }}$, mean temperatures in January $\mathrm{T}_{\text {January }}$ and July $\mathrm{T}_{\text {July, }}$, and the average number of days with temperatures below zero $\mathrm{N}_{\mathrm{T}<0}$ (as an estimate of winter length) were compiled from data in Weatherbase (http://www.weatherbase.com) and the yearly temperature difference $\Delta \mathrm{T}$ of a country or island was estimated using $\Delta \mathrm{T}=\mathrm{T}_{\text {July }}$ $-\mathrm{T}_{\text {January }}$. Average precipitation and humidity for each country was not used because in many cases high mountain areas biased the data. Further more the temperature ranges of large countries are over stated. Latitude is highly correlated with different climate variables linked to temperature (like average, minimum and maximum temperatures, winter length, numbers of days below $0^{\circ} \mathrm{C}$ etc.) and can be used as an aggregate variable for a general temperature gradient (Hawkins et al., 2007; Ulrich et al., 2007; Ulrich \& Fiera, 2009). $\Delta \mathrm{T}$ in turn is only weakly positively correlated with latitude (Pearson $r=0.40$ ).

Further, data on the number of vascular plants was compiled from data in EarthTrends: The Environmental Information Portal (http://earthtrends.wri.org) and used as an estimate of habitat heterogeneity. However, because there is reliable data for only 6 islands and 35 countries the numbers of plant species were not include in the basic model. Data on productivity and evapotranspiration were not included because of lack of sufficiently precise data. Both these variables are known to be important aggregate variables influencing broad scale patterns in species richness (Hawkins et al., 2003).

Sesiid species richness appeared to be spatially autocorrelated (Moran's I of first distance class: $\mathrm{I}=0.64 ; \mathrm{P}(\mathrm{I}=0)<0.001)$. To correct for spatial autocorrelation the simultaneous autoregression model (Lichstein et al., 2002; Kissling \& Carl, 2007; Bini et al., 2009) with generalized least squares estimation that is implemented in the Spatial Analysis in the Macroecology (SAM v. 3.0) package of Rangel et al. (2006), was used. Because the SARs are most often of the power function type, species richness and area are entered as $\ln$-transformed data. Errors refer to standard errors.

\section{RESULTS}

Island and mainland SARs were best described by the power function model (Fig. 2) with slopes of $z=0.28$ (islands) and $\mathrm{z}=0.27$ (mainlands). However, the low coefficients of determination (both $\mathrm{R}^{2}<0.4$ ) show that area is only a weak descriptor of species richness in Sesii-
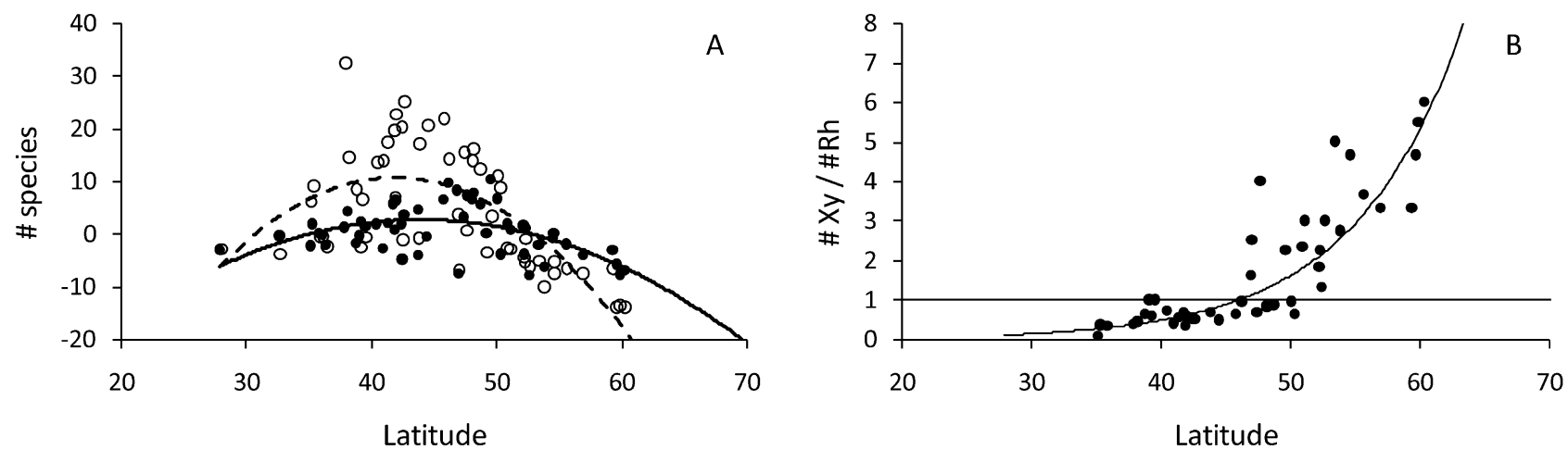

Fig. 3. A: Residuals of SARs of rhizophagous (open circles) and xylophagous (dots) Sesiidae show the latitudinal gradient in area corrected species richness. Dashed quadratic regression line (rhizophagous): $\mathrm{R}^{2}=0.48$; $\mathrm{p}$ (quadratic term $=0$ ) $<0.001$; continuous regression line (xylophagous): $\mathrm{R}^{2}=0.31$; $\mathrm{p}$ (quadratic term $=0$ ) $<0.001$. In both cases SARs and residuals were calculated separately for islands and mainland. B: Quotient of species richness of xylophagous Sesiidae (\#Xy) over species richness of rhizophagous Sesiidae (\#Rh) dependence on latitude shows that there is a relative increase in xylophagous species with latitude. Regression: $\mathrm{Y}=0.0041 \mathrm{e}^{0.12 x} ; \mathrm{R}^{2}=0.76 ; \mathrm{P}$ (no correlation) $<0.0001$. 


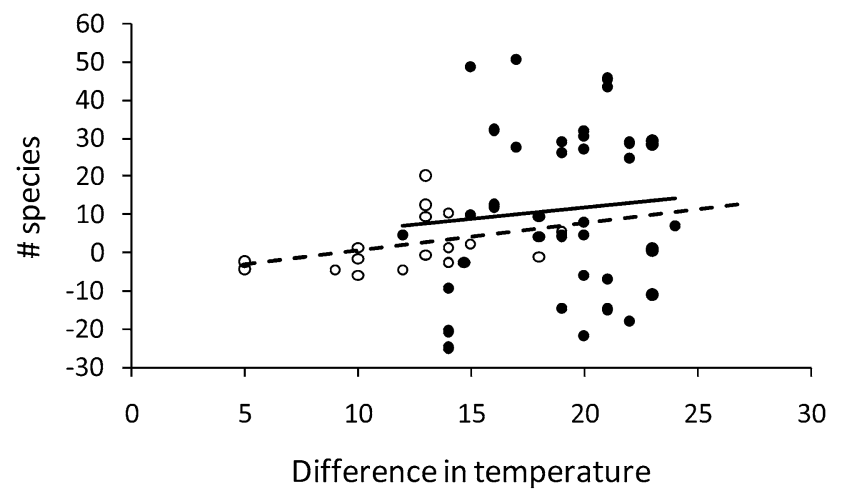

Fig. 4. The dependence of the residuals of island (open circles) and mainland (dots) SARs (Fig. 1) on annual temperature difference does not point to an increase in species richness with $\Delta \mathrm{T}$. Both regression lines are statistical insignificant at the $5 \%$ error benchmark.

dae. Island and mainland SAR slopes did not differ significantly, however island species richness per unit area appeared to be about 2 to 2.5 times lower than that on the mainland (Fig. 2). Of the countries for which reliable data were available (Fig. 1; Table 1), Greece appeared to be most species rich (62 species), followed by Italy (59), Bulgaria and France (56).

Area corrected species richness of rhizophagous Sesiidae (Fig. 3A) peaked at about $40^{\circ} \mathrm{N}$ and decreased sharply towards higher and moderately towards lower latitudes. Most species rich were Greece (45 species), Bulgaria (37), Italy (35) and Romania (35) (Table 1). In turn, the area corrected species richness of xylophagous Sesiidae peaked at about $45^{\circ} \mathrm{N}$ with France (24) and Italy (22) the most species rich (Table 1). The peak in species

TABLE 2. Spatial autoregression model describing the $\ln$ transformed species richness of Sesiidae in Europe. $\mathrm{N}=54$; Complete model: $\mathrm{R}^{2}=0.74 ; \mathrm{P}(\mathrm{t})<0.001$; Best fit model: $\mathrm{R}^{2}=$ $0.74 ; \mathrm{P}(\mathrm{t})<0.001$.

\begin{tabular}{|c|c|c|c|c|}
\hline \multicolumn{5}{|c|}{ Complete Model } \\
\hline Variable & Coefficient & St. Error & $\mathrm{t}$ & $\mathrm{P}$ \\
\hline Constant & -13.233 & 3.700 & -3.577 & $<0.001$ \\
\hline $\ln$ Area & 0.375 & 0.054 & 7.235 & $<0.001$ \\
\hline Elevation/Area & 0.025 & 0.011 & 2.276 & 0.030 \\
\hline$\Delta \mathrm{T}$ & 0.041 & 0.055 & 0.755 & 0.454 \\
\hline Temp & 0.025 & 0.056 & 0.442 & 0.661 \\
\hline $\mathrm{N}_{\mathrm{T}<0}$ & 0.002 & 0.003 & 0.563 & 0.576 \\
\hline Longitude & 0.005 & 0.015 & 0.371 & 0.712 \\
\hline Latitude & 0.518 & 0.141 & 3.684 & $<0.001$ \\
\hline Latitude $^{2}$ & -0.006 & 0.001 & -4.143 & $<0.001$ \\
\hline \multicolumn{5}{|c|}{ Best fitting model } \\
\hline Variable & Coefficient & St. Error & $\mathrm{t}$ & $\mathrm{P}$ \\
\hline Constant & -11.157 & 2.909 & -3.836 & $<0.001$ \\
\hline $\ln$ Area & 0.327 & 0.042 & 7.718 & $<0.001$ \\
\hline$\Delta \mathrm{T}$ & 0.068 & 0.026 & 2.632 & 0.011 \\
\hline Latitude & 0.464 & 0.131 & 3.538 & $<0.001$ \\
\hline Latitude $^{2}$ & -0.005 & 0.001 & -3.912 & $<0.001$ \\
\hline
\end{tabular}

TABLE 3. Best fitting spatial autoregression models describing the $\ln$-transformed species richness of rhizophagous and xylophagous Sesiidae in Europe. Rhizophagous: $\mathrm{N}=54 ; \mathrm{R}^{2}=0.72$; $\mathrm{P}(\mathrm{t})<0.001$. Xylophagous: $\mathrm{N}=54 ; \mathrm{R}^{2}=0.74 ; \mathrm{P}(\mathrm{t})<0.001$.

\begin{tabular}{lrcrc}
\hline \multicolumn{5}{c}{ Rhizophagous } \\
\hline Variable & Coefficient & St. Error & $\mathrm{t}$ & $\mathrm{P}$ \\
\hline Constant & -13.357 & 2.689 & -4.968 & $<0.001$ \\
ln Area & 0.295 & 0.037 & 8.016 & $<0.001$ \\
Latitude & 0.533 & 0.119 & 4.469 & $<0.001$ \\
Latitude $^{2}$ & -0.006 & 0.001 & -4.323 & $<0.001$ \\
\hline \multicolumn{5}{c}{ Xylophagous } \\
\hline Variable $^{5}$ Coefficient & St. Error & $\mathrm{t}$ & $\mathrm{P}$ \\
\hline Constant & -12.177 & 3.062 & -3.87 & $<0.001$ \\
ln Area & 0.316 & 0.044 & 7.174 & $<0.001$ \\
$\Delta \mathrm{T}$ & 0.073 & 0.027 & 2.554 & 0.014 \\
Latitude $^{5}$ & 0.543 & 0.138 & 3.819 & $<0.001$ \\
Latitude $^{2}$ & -0.007 & 0.001 & -4.627 & $<0.001$ \\
\hline
\end{tabular}

richness was less pronounced than that observed for the rhizophagoues species. A plot of the quotient of xylophagous to rhizophagous species richness $(\mathrm{Xy} / \mathrm{Rh})$ against latitude revealed that xylophagous species are dominant in countries north of $50^{\circ} \mathrm{N}$ and rhizophagous species dominant in countries south of $45^{\circ} \mathrm{N}$ (Fig. 3 B).

Because the simple species richness analysis revealed peaks in species richness at intermediate latitudes we used linear and quadratic latitudinal terms in the spatial autoregression modelling. Total species richness (Table 2) and richness of rhizophagous and xylophagous species (Table 3 ) were significantly positively correlated with area. The average yearly difference in temperature, $\Delta \mathrm{T}$, was included in the best fitting models of the whole fauna and of xylophagous species only, although a plot of area corrected species richness did not indicate that $\Delta \mathrm{T}$ is a major predictor of sesiid species richness in Europe (Fig. 4). Geographical heterogeneity, measured by the quotient $H$ of highest altitude and area (Table 1), appeared to have a weak effect $(\mathrm{P}=0.03)$, which is, however statistically insignificant after Bonferroni correction for multiple testing $\left(\mathrm{P}_{\text {corr }}>0.20\right)$.

As expected from the above described latitudinal trends the quadratic terms for latitude were in all cases negative and always highly significant. The latitude and $\Delta \mathrm{T}$ corrected SAR slope was $\mathrm{z}=0.295$ for rhizophagous and $\mathrm{z}=$ 0.316 for xylophagues species. Both slopes did not differ significantly $[\mathrm{P}(\mathrm{t}$-test $)>0.05]$. The magnitude of the lati-

TABLE 4. Best fitting model describing sesiid species richness in Europe when vascular plant species richness $\left(\mathrm{S}_{\text {vascular plants }}\right)$ is included. $\mathrm{N}=31 ; \mathrm{R}^{2}=0.71 ; \mathrm{P}<0.001$.

\begin{tabular}{lrrrr}
\hline Variable & Coefficient & St. Error & $\mathrm{t}$ & $\mathrm{P}$ \\
\hline Constant & -18.464 & 4.602 & -3.965 & $<0.001$ \\
ln Area & 0.341 & 0.051 & 6.645 & $<0.001$ \\
Latitude & 0.835 & 0.214 & 3.864 & $<0.001$ \\
Latitude $^{2}$ & -0.009 & 0.002 & -3.817 & $<0.001$ \\
S $_{\text {vascular plants }}$ & $<0.001$ & $<0.001$ & -0.906 & 0.374 \\
\hline
\end{tabular}


tudinal gradients for both guilds was also similar (Table 3 ). The complete model (Table 2) revealed that longitude, country/island heterogeneity $H$, winter length and average annual temperature did not significantly influence patterns of species richness. A separate spatial modelling using only those islands/countries with reliable data for vascular plant species richness did not point to plant species richness as a significant predictor of sesiid species richness (Table 4).

\section{DISCUSSION}

Sesiidae occur in most of Europe up to the tundra in the north and the subalpine and partly alpine zones in the mountains. Their present distribution is the result of climatic changes and opportunities for spreading from glacial refugia after the end of the Glacial Era and to a considerable degree, also the influence of man-made changes to habitats throughout Europe after the Atlantic epoch. Moreover, the distribution of some species was probably directly affected by introduction with their host-plants (Laštůvka \& Laštůvka, 2001). This pattern is particularly apparent in widespread xylophagous species that develop in fruit plants, ornamental or woody forest species, or in agriculture crops and occur from the boreal to the Mediterranean zone. Of the rhizophagous species only Bembecia ichneumoniformis has a comparable tolerance of climate.

This study confirms previous work on European arthropod species richness (Ulrich \& Buszko, 2003a; Baselga, 2008; Ulrich et al., 2007; Ulrich \& Fiera, 2009) and identified area, latitude and absolute temperature difference as major drivers of species richness (Tables 2, 3). Latitude is an aggregate variable that includes the effects of several climatic variables, like snow cover, temperature, humidity, or length of seasons (Hawkins et al., 2007). Hence this study adds support to the hypothesis that arthropod species richness primarily depends on area and climate. However, geographical heterogeneity did not significantly influence species richness (Table 2). In this respect clearwing moths differ from European butterflies for which heterogeneity is a significant predictor of species richness (Konvička et al., 2006).

The present results have implications for the identification of clearwing hot spots. Area corrected richness of rhizophagous species peaked in Greece (45 species), Bulgaria (37), Italy (35) and Romania (35), while that for xylophagous Sesiidae peaked in France (24) and Italy (22). Hence the distribution of rhizophagous species accords with the hypotheses that the main centre of postglacial invasions of arthropods and plants was the southern part of the Balkans and Turkey (Medail \& Quezel, 1997; Svenning \& Skov, 2007). There are about 100 species of clearwing moths in Turkey (Špatenka et al., 1999) and therefore far more than any European country. On the other hand, there is no significant longitudinal trend in species richness, which should be the case if the invasion was from the south-east (Ulrich \& Fiera, 2009). A similar pattern in bats (Ulrich et al., 2007) is explained by an additional postglacial centre on the Iberian Peninsula.

Latitude and climate corrected sesiid SAR slopes $(\mathrm{z}=$ 0.30 to 0.38 ; Tables 2, 3) are higher than those reported for many other arthropod taxa (Rosenzweig, 1995; Drakare et al., 2006). However, contrary to recent theories, island and mainland SAR slopes were nearly identical (Fig. 2). Most studies report that slopes for islands are steeper than that for the mainland indicating higher beta diversity on islands (Connor \& McCoy, 1979; Rosenzweig, 1995; Dennis et al., 2008; Ulrich \& Fiera, 2009). In turn, species densities (number of species per unit area) on islands appear to be at least two times lower than on mainland (Fig. 2). This finding is in accordance with previous comparisons of patterns of diversity on islands and mainland (Drakare et al., 2006) and recent approaches to the theory of island biogeography (Brown \& Lomolino, 2005).

This study also confirms previous suggestions that rhizophagous and xylophagous sesiid species have different distributions (Špatenka et al., 1999). Xylophagous Sesiidae occur predominately north of the Alps while rhizophagous sesiid diversity peaks in Mediterranean countries (Fig. 3). This is indicated also by the fact that many Mediterranean herbaceous host species of rhizophagous clearwings live only in the southernmost part of France and several xylophagous Italian and Spanish species live only in northernmost parts of these countries.

The present modeling corroborates previous work on butterflies (Ulrich \& Buszko, 2003a, b, Konvička et al., 2006), bats (Ulrich et al., 2007), Cerambycidae (Baselga, 2008) and Collembola (Ulrich \& Fiera, 2009), which show that even coarse grained data (whole country species richness and climate variables) are able to identify major environmental predictors of insect species richness (but see Bustamante \& Seoane, 2004). These results hopefully will encourage others to do similar analyses of recent faunal data of other large taxa. This would greatly increase our understanding of the environmental correlates of large scale arthropod species richness.

ACKNOWLEDGEMENTS. N. Ryrholm kindly improved our English. This work was in part supported by a grant from the Ministry of Education, Youth and Sports of the Czech Republic No. MSM6215648905.

\section{REFERENCES}

BARTSCH D. 2004: Die Sesienfauna Zyperns - eine kommentierte Übersicht (Lepidoptera: Sesiidae). Entomol. Z. 114: 80-86.

Bartsch D. \& Kallies A. 2008: Zur Kenntnis einiger Arten von Chamaesphecia Spuler, 1910 in Marokko (Lepidoptera: Sesiidae). Entomol. Z. 118: 85-93.

Bartsch D. \& PÜhringer F. 2005: Die Glasflügler Kretas (Lepidoptera: Sesiidae). Entomol. Z. 115: 131-139.

Bartsch D., Pühringer F., Bettag E. \& Blum E. 2005: Chamaesphecia gorbunovi Špatenka, 1992 - eine bisher für die europäische Fauna verkannte Sesienart (Lepidoptera: Sesiidae). Entomol. Z. 115: 177-180. 
Baselga A. 2008: Determinants of species richness, endemism and turnover in European longhorn beetles. Ecography 31: 263-271.

Bini L.M, Diniz J.AF., Rangel T.F.L.V.B, Akre T.S.B, Albaladejo R.G, Albuquerque F.S, Aparicio A., Araujo M.B., Baselga A., Beck J., Bellocq M.I., Bohning-Gaese K., Borges P.A.V., Castro-Parga I., Chey V.K., Chown S.L., De Marco P., Dobkin D.S., Ferrer-Castan D., Field R., Filloy J., Fleishman E., Gomez J.F., Hortal J., Iverson J.B., Kerr J.T., Kissling W.D., Kitching I.J., Leon-Cortes J.L., Lobo J.M., Montoya D., Morales-Castilla I., Moreno J.C., OberdorfF T., Olalla-Tarraga M.A., Pausas J.G., Qian H., Rahbek C., Rodriguez M.A., Rueda M., Ruggiero A., Sackmann P., Sanders N.J., Terribile L.C., Vetaas O.R. \& Hawkins B.A. 2009: Coefficient shifts in geographical ecology: an empirical evaluation of spatial and non-spatial regression. Ecography 32: 193-204.

Brown J.H. \& Lomolino M.V. 2005: Biogeography. Sinauer, Sunderland, $752 \mathrm{pp}$.

Bustamante J. \& Seonne J. 2004: Predicting the distribution of four species of raptors (Aves: Accipitridae) in southern Spain: statistical models work better than existing maps. J. Biogeogr. 31: 295-306.

Connor E.F. \& McCoy E.D. 1979: The statistics and biology of the species-area relationship. Am. Nat. 113: 791-833.

Currie D.J, Mittelbach G.G, Cornell H.V, Field R., Guégan J.F, Hawkins B., Kaufman D.M., Kerr J.T., Oberdorff T. \& Turner J.R.G. 2004. Predictions and tests of climate-based hypotheses of broad-scale variation in taxonomic richness. Ecol. Lett. 7: 1121-1134.

Dengler J. 2009: Which function describes the species-area relationship best? A review and empirical evaluation. J. Biogeogr. 36: 728-744.

Dennis R.H.L., Williams W.R. \& Shreeve T.G. 1998: Faunal structures among European butterflies: evolutionary implications of bias for geography, endemism and taxonomic affiliation. Ecography 21: 181-203.

Dennis R.L.H., Dapporto L., Shreeve T.G., John E., Coutsis J.G., Kudrna O., SaArinen K., Ryrholm N. \& Williams W.R. 2008: Butterflies of European islands: the implications of the geography and ecology of rarity and endemicity for conservation. J. Insect Conserv. 12: 205-236.

Drakare S., Lennon J.J. \& Hillebrand H. 2006: The imprint of the geographical, evolutionary and ecological context on species-area relationships. Ecol. Lett. 9: 215-227.

Field R., Hawkins B.A., Cornell H.V., Currie D.J., Diniz-Filho J.A.F., GuÉgan J.-F., Kaufman D.M., Kerr J.T., Mittelbach G.G., OBerdorff T.T., O'Brien E.M. \& Turner J.R.G. 2008: Spatial species-richness gradients across scales: a meta analysis. J. Biogeogr. 36: 132-147.

Hawkins B.A. \& Diniz-Filho J.A.F. 2004: "Latitude" and geographic patterns in species richness. Ecography 27: 268-272.

Hawkins B.A., Field R., Cornell H.V., Currie D.J., Guegan J.F., Kaufman D.M., Kerr J.T., Mittelbach G.G., OberdorfF T., O’Brien E.M., Porter E.E. \& Turner J.R.G. 2003: Energy, water, and broad-scale geographic patterns of species richness. Ecology 84: 3105-3117.

Hawkins B.A., Diniz-Filho J.A.F., Jaramillo C.A. \& Soeller S.A. 2007: Climate, niche conservatism and the global bird diversity gradient. Am. Nat. 170: 516-527.

Hillebrand H. 2004: On the generality of the latitudinal diversity gradient. Am. Nat. 163: 192-211.

HorÁĆEK I., HANÁK V. \& Gaisler J. 2000: Bats of the Palearctic Region: A taxonomic and biogeographic review. In Wołoszyn B.W. (ed.): Proceedings of the VIIIth EBRS. Vol. 1. Approaches to Biogeography and Ecology of Bats. Chiro- pterological Information Center ISEZ PAN, Kraków, pp. 11-157.

KeIL P. \& KonvičKa M. 2005: Local species richness of Central European hoverflies (Diptera: Syrphidae): a lesson taught by local faunal lists. Diver. Distr. 11: 417-426.

Keil P., Dziock F. \& Storch D. 2008a: Geographical patterns of hoverfly (Diptera, Syrphidae) functional groups in Europe: inconsistency in environmental correlates and latitudinal trends. Ecol. Entomol. 33: 748-757.

Keil P., Simova I. \& Hawkins B.A. 2008b: Water-energy and the geographical species richness pattern of European and North African dragonflies (Odonata). Insect Conserv. Div. 1: $142-150$.

KissLing W.D. \& CARL G. 2008: Spatial autocorrelation and the selection of simultaneous autoregressive models. Gl. Ecol. Biogeogr. 17: 59-71.

Кокот A. 2005: Synanthedon soffneri Špatenka, 1983 (Lepidoptera, Sesiidae) new to the Polish fauna. Acta Entomol. Siles. 12/13: 163-164.

KonVIČKa M., Fric Z. \& Beneš J. 2006: Butterfly extinctions in European states: do socioeconomic conditions matter more than physical geography? Gl. Ecol. Biogeogr. 15: 82-92.

LAŠTU゚VKA Z. 1990: Eine Übersicht der Futterpflanzen der europäischen Glasflügler (Lepidoptera, Sesiidae). Acta. Univ. Agric. (Brno), Fac. Agron. 37: 153-162.

LAŠTU゚VKA Z. 2004: Sesiidae. In Karsholt O. \& Nieukerken E.J. van (eds): Fauna Europaea: Lepidoptera, Moths. Fauna Europaea. Version 1.3, online at http://www.faunaeur.org/ (as of 19 April 2007).

LAŠTƯVKA Z. \& LAŠTUீVKa A. 2001: The Sesiidae of Europe. Apollo Books, Stenstrup, 245 pp.

LAŠTU゚VKA Z. \& LAŠTU゚VKA A. 2008: Synanthedon mesiaeformis (Herrich-Schäffer) new to the Czech Republic and to Spain (Lepidoptera: Sesiidae). Acta Univ. Agric. Silvic. Mendel. Brun. 56(5): 141-146.

Lichstein J.W., Simons T.R., Shriner S.A. \& Franzreb K.E. 2002: Spatial autocorrelation and autoregressive models ecology. Ecol. Monogr. 72: 445-463.

LUMARET J.P. \& LoBo J.M. 1996: Geographic distribution of endemic dung beetles (Coleoptera, Scarabaeoidea) in the western Palaearctic region. Biodiv. Lett. 3: 192-199.

MacArthur R.H. \& Wilson E.O. 1967: The Theory of Island Biogeography. Princeton Univ. Press., Princeton, 203 pp.

MéDAIL F. \& Quézel P. 1997: Hot-spots analysis for conservation of plant biodiversity in the Mediterranean Basin. Ann. Missouri Bot. Gard. 84: 112-127.

Predovnik Z. 2005: Clearwing moths (Lepidoptera: Sesiidae) new to the fauna of Slovenia. Acta Entomol. Sloven. 13: 93-102.

Rangel T.F.L., Diniz-Filho J.A.F. \& Bini L.M. 2006: Towards an integrated computational tool for spatial analysis in macroecology and biogeography. Gl. Ecol. Biogeogr. 15: 321-327.

Ricklefs R.E., Hong Q. \& White P.S. 2004: The region effect on mesoscale plant species richness between eastern Asia and eastern North America. Ecography 27: 129-136.

RoHDE K. 1992: Latitudinal gradients in species diversity: the search for the primary cause. Oikos 65: 514-527.

Rosenzweig M.L. 1995: Species Diversity in Space and Time. Cambridge University Press, Cambridge, 436 pp.

Špatenka Z., Gorbunov O., Laštưvka Z., TosevSKi I. \& ARita Y. 1999: Handbook of Palaearctic Macrolepidoptera. Vol. 1. Sesiidae - Clearwing Moths. GEM Publishing, Wallingford, $569 \mathrm{pp}$. 
Svenning J.C. \& Skov F. 2007: Ice ace legacies in the geographical distribution of tree species richness in Europe. $G l$. Ecol. Biogeogr. 16: 234-245.

Ulrich W. \& Buszko J. 2003a: Species-area relationships of butterflies in Europe and species richness forecasting. Ecography 26: 365-374.

Ulrich W. \& Buszko J. 2003b: Self-similarity and the species area relation of Polish butterflies. Basic Appl. Ecol. 4: 263-270.
Ulrich W., Sachanowicz K. \& Michalak M. 2007: Environmental correlates of species richness of European bats (Mammalia: Chiroptera). Acta Chiropterol. 9: 347-360.

Ulrich W. \& Fiera C. 2009: Environmental correlates of species richness of European springtails (Hexapoda: Collembola). Acta Oecol. 35: 45-52.

WiLlig M.R, Kaufman D.M. \& Stevens R.D. 2003: Latitudinal gradients of biodiversity: pattern, process, scale, and synthesis. Annu. Rev. Ecol. Syst. 34: 273-309.

Received December 18, 2009; revised and accepted March 8, 2010 